\title{
Seasonal patterns in asthma hospitalization in Saskatchewan, 1979 to 1989
}

\author{
Sreelatha Meleth MSc, A Senthilselvan PhD \\ Department of Community Health and Epidemiology, College of Medicine, \\ University of Saskatchewan, Saskatoon, Saskatchewan
}

S Meleth, A Senthilselvan. Seasonal patterns in asthma hospitalization in Saskatchewan, 1979 to 1989. Can Respir J 1997;4(5):263-268.

OBJECTIVES: To determine whether monthly asthma hospitalization rates in Saskatchewan exhibited a seasonal pattern. Rates were studied from January 1979 to December 1989.

PATIENTS: The age groups studied were aged birth to four years, aged five to 14 years, 15 to 34 years, 35 to 49 years and 50 to 65 years. Sex differences in seasonal patterns in asthma hospitalization rates were also investigated. METHODS: The hospitalization data for asthma were obtained for the province of Saskatchewan from 1979 to 1989 , inclusive. The time series was decomposed into its trend, seasonal and error component, using an additive model. Significance of the components was tested using a two-way ANOVA.

RESULTS: Seasonal variations were observed in the monthly asthma hospitalization rates among Saskatchewan residents. Increases in asthma hospitalization rates were observed in the spring and fall months among children, in summer months among young adults aged 15 to 34 years and in winter months among the older age groups. Seasonal patterns in asthma hospitalization rates were similar for males and females in children and in adults aged 50 to 64 years. In young adults aged 15 to 34 years, increased asthma hospitalization rates were observed in spring months among men and in both spring and fall months among women. The 35- to 49-year-old men did not exhibit a statistically significant seasonal pattern, whereas the women did. No sex differences in seasonal patterns of asthma hospitalization rates were statistically significant. CONCLUSIONS: Seasonal patterns were observed in asthma hospitalization rates for residents of Saskatchewan. Asthma hospitalizations were greater in spring and fall seasons for children and in winter for the older adults. More studies are required to examine possible reasons for these seasonal differences in asthma hospitalizations.

Key Words: Asthma, Hospitalization, Seasonality, Sex differences

Tendances saisonnières dans les hospitalisations liées à l'asthme en Saskatchewan de 1979 à 1989

OBJECTIFS : Déterminer si les hospitalisations liées à l'asthme en Saskatchewan présentent des tendances saisonnières. Les taux d'hospitalisation ont été examinés de janvier 1979 à décembre 1989.

PATIENTS : Les groupes d'âge étudiés allaient de la naissance à 4 ans, de 5 ans à 14 ans, de 15 à 34 ans, de 35 à 49 ans et de 50 à 65 ans. Les différences de sexe dans les tendances saisonnières des hospitalisations liées à l'asthme ont aussi été examinées.

The authors, not the Urban Hospitals Services Branch, Saskatchewan Health Department, are responsible for the study and its conclusions

Correspondence and reprints: Dr A Senthilselvan, Department of Community Health and Epidemiology, University of Saskatchewan, 107 Wiggins Road, Saskatoon, Saskatchewan S7N 5E5. Telephone 306-966-7941, fax 306-966-7920, e-mail sentil@ sask.usask.ca 
MÉTHODES : Les données sur les hospitalisations liées à l'asthme provenaient de la province de Saskatchewan de 1979 à 1989 inclusivement. La série temporelle a été décomposée en tendance saisonnière et en composante d'erreur, en utilisant un modèle additif. La signification des composantes a été testée en utilisant une analyse de variance à double entrée.

RÉSULTATS : Des variations saisonnières ont été observées dans les taux mensuels d'hospitalisations liées à l'asthme parmi les résidents de la Saskatchewan. Les augmentations dans les hospitalisations liées à l'asthme ont été observées au printemps et en automne parmi les enfants, en été chez les jeunes adultes de 15 à 34 ans, et en hiver dans les groupes plus âgés. Les tendances saisonnières des taux d'hospitalisation liés à l'asthme étaient similaires pour les garçons et les filles et pour les hommes et les femmes âgés de 50 à 64 ans. Chez les jeunes adultes de 15 à 34 ans, l'augmentation des taux d'hospitalisation a été observée au printemps chez les individus de sexe masculin et, à la fois au printemps et à l'automne parmi les femmes. Les hommes de 35 à 49 ans ne présentaient pas de tendance saisonnière significative tandis que cette tendance pouvait s'observer chez les femmes. Toutefois, les différences liées au sexe dans les tendances des hospitalisations liées à l'asthme n'étaient pas significatives sur le plan statistique.

CONCLUSIONS : Les tendances saisonnières ont été observées dans les taux des hospitalisations liées à l'asthme chez les résidents de la Saskatchewan. Les hospitalisations étaient plus nombreuses au printemps et en automne chez les enfants et en hiver chez les adultes. Il est nécessaire de procéder à d'autres études pour examiner les raisons possibles de ces différences saisonnières dans les hospitalisations liées à l'asthme.
A sthma is a common condition, affecting about half a million people in Canada (1). In clinical practice two forms of asthma are commonly found. Extrinsic asthma, in which an exogenous causal factor is involved, generally begins at an early age and affects boys more often than girls. Intrinsic asthma begins later and strikes men and women equally (2). Extrinsic asthma or asthma attacks that follow exposure to some allergic agent are also called atopic asthma. There is evidence that suggests the environment has an important role to play in both the prevalence of atopy and asthma. This is backed up by surveys in developing countries that suggest populations living in very poor rural areas have a low prevalence of bronchial hyper-responsiveness, but that this prevalence increases rapidly as populations move to urban and more affluent areas $(3,4)$. This role of the environment in asthma is further supported by evidence of seasonal patterns in asthma morbidity. It is now well established that many asthma patients experience a worsening of their symptoms and a greater frequency of attacks at certain times of the year $(5,6)$.

A number of studies have been conducted in many different countries to study seasonal patterns in asthma (7-16). Comparing these studies is a problem because the studies have been completed on widely diverse age groups and patients from widely disparate settings. The studies are also limited in that they either studied a very small section of the population or used age groupings that were too large to detect changes in the different populations.

In Canada, Saskatchewan and the Maritime provinces have the highest hospital admission rates for asthma (17). Hospitalization rates for asthma increased significantly among the birth to aged four years group between 1979 and 1989, but did not increase in any other age group (18). Saskatchewan, along with Alberta, also has the highest mortality rate for asthma (17). The aim of this study was to study seasonal patterns in asthma morbidity to investigate sex differences in seasonal patterns in asthma hospitalizations in Saskatchewan. The age groups studied were aged birth to four years, five to 14 years, 15 to 34 years, 35 to 49 years, and 50 to 65 years. To the best of our knowledge no study has examined the differences or similarities in seasonal patterns between the sexes in these age groups.

\section{PATIENTS AND METHODS}

Saskatchewan is a prairie province of Canada with a population of 1.01 million people. Agriculture is the main occupation of the people in Saskatchewan. The population is a mixture of Caucasians, Aboriginal Indians and people of many other ethnic origins. A majority of the Aboriginal Indian population belongs to bands that have signed treaties with the federal government and are called as Registered Indians. The Registered Indian population can be identified from the Saskatchewan Health administrative databases by health insurance number. Because hospitalization patterns for asthma were found to be different for the Registered Indian population (19), they were excluded from this study. The government of Saskatchewan provides universal health care insurance to all people living in Saskatchewan. This study looked at monthly hospitalization rates for asthma in the years from 1979 to 1989 , and examined the rates for seasonal patterns.

Hospital discharge information for all 134 provincial hospitals was obtained from the Urban Hospitals Branch of the Saskatchewan Health Department. The raw data provided included the year and month of separation, and age and sex of a patient. The data were first divided into the desired age groups - age birth to four years, five to 14 years, 15 to 34 years, 35 to 49 years, and 50 to 65 years - and the total separations in each age group for each month of each year was obtained. The population for each year in these age groups was obtained from the Covered Population tables published by Saskatchewan Health (20). The hospitalization rate for each month of each year was then obtained by dividing the number of separations in the age group for that month by the corresponding mid-year population for that year.

Statistical methods: The time series was decomposed into several components. In this method, time series are generally considered to be a mixture of four components: a trend across years; a seasonal component; a cyclical pattern; and a random component. The seasonal component is assumed to change very slowly or remain practically constant. The cyclical pattern is a pattern that is repeated over periods of different lengths that generally are longer than one year. The relationship between trend, seasonal and random components is assumed to be additive or multiplicative. The plot of 
TABLE 1

Average age-specific monthly asthma hospitalization rates in Saskatchewan, 1979 to 1989

\begin{tabular}{|c|c|c|c|c|c|}
\hline Month & $\begin{array}{c}\text { Birth to } 4 \text { years } \\
\text { Mean (SD) }\end{array}$ & $\begin{array}{l}5 \text { to } 14 \text { years } \\
\text { Mean (SD) }\end{array}$ & $\begin{array}{c}15 \text { to } 34 \text { years } \\
\text { Mean (SD) }\end{array}$ & $\begin{array}{c}35 \text { to } 49 \text { years } \\
\text { Mean (SD) }\end{array}$ & $\begin{array}{c}50 \text { to } 64 \text { years } \\
\text { Mean (SD) }\end{array}$ \\
\hline January & $0.57(0.28)$ & $0.20(0.07)$ & $0.07(0.04)$ & $0.10(0.05)$ & $027(0.07)$ \\
\hline February & $0.61(0.40)$ & $0.21(0.08)$ & $0.06(0.04)$ & $0.09(0.05)$ & $0.22(0.06)$ \\
\hline March & $0.65(0.37)$ & $0.28(0.08)$ & $0.09(0.04)$ & $0.11(0.05)$ & $0.28(0.06)$ \\
\hline April & $0.77(0.34)$ & $0.35(0.10)$ & $0.09(0.04)$ & $0.10(0.05)$ & $0.27(0.08)$ \\
\hline May & $0.87(0.49)$ & $0.46(0.18)$ & $0.10(0.04)$ & $0.10(0.06)$ & $0.25(0.07)$ \\
\hline June & $0.67(0.32)$ & $0.42(0.13)$ & $0.09(0.03)$ & $0.08(0.04)$ & $0.22(0.06)$ \\
\hline July & $0.48(0.22)$ & $0.28(0.18)$ & $0.09(0.05)$ & $0.07(0.03)$ & $0.17(0.04)$ \\
\hline August & $0.40(0.21)$ & $0.30(0.23)$ & $0.10(0.03)$ & $0.07(0.03)$ & $0.18(0.05)$ \\
\hline September & $0.74(0.36)$ & $0.62(0.18)$ & $0.13(0.05)$ & $0.09(0.04)$ & $0.19(0.07)$ \\
\hline October & $0.77(0.32)$ & $0.44(0.15)$ & $0.12(0.04)$ & $0.11(0.05)$ & $0.21(0.07)$ \\
\hline November & $0.68(0.33)$ & $0.32(0.06)$ & $0.10(0.04)$ & $0.09(0.04)$ & $0.19(0.07)$ \\
\hline December & $0.54(0.31)$ & $0.22(0.06)$ & $0.09(0.04)$ & $0.11(0.08)$ & $0.25(0.07)$ \\
\hline
\end{tabular}

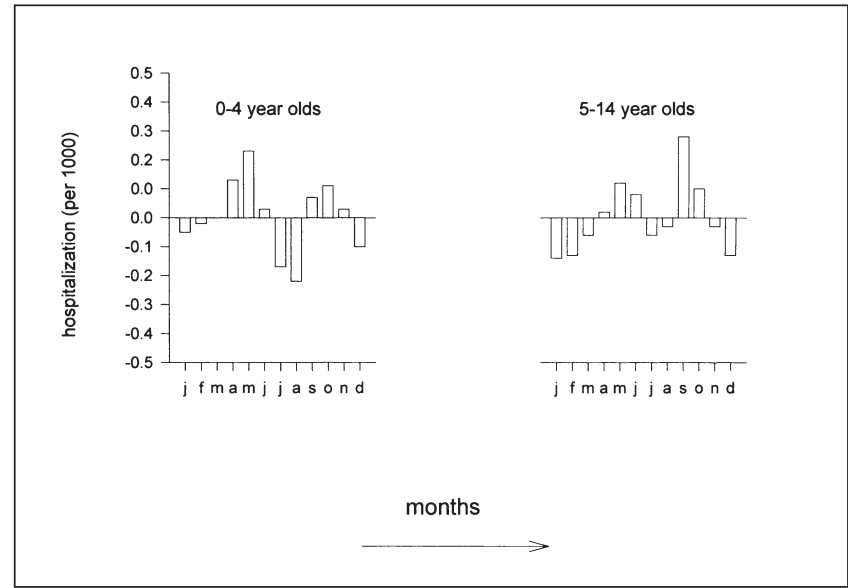

Figure 1) Seasonal patterns in asthma hospitalization rates for children in Saskatchewan, 1979 to 1989

rates against months was examined to determine whether an additive or multiplicative model was more appropriate. An additive model seemed to be more suitable for the asthma hospitalization data considered in this study. The time series plot did not reveal prominent cyclical patterns.

To test whether seasonal estimates obtained from the additive model were a statistically significant variation in the hospitalization rates, F-statistic in an ANOVA table was used. ANOVA has been used previously to test seasonality in time series (21). MacLeod et al (21) used three ANOVA tables to test for what they referred to as 'stable seasonality'. In the first instance, the hospitalization rates were examined for a statistically significant variation between the years (trend), between the months (seasonality) or both. The trend value was then subtracted from the series, and the detrended series was tested for variation between years and between months. If the seasonal variation was statistically significant, the seasonal estimates calculated from the series were subtracted from the detrended series, and a third ANOVA was run. The detrended and deseasonalized series should exhibit only random variation. Sex differences in seasonal patterns in asthma hospitalizations were investigated by testing interactions between sex and month in the detrended series.

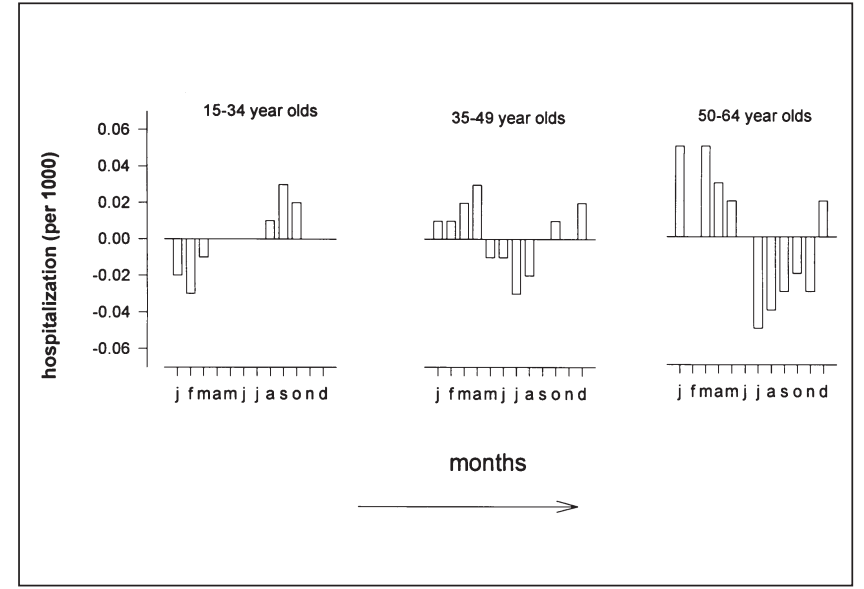

Figure 2) Seasonal patterns in asthma hospitalization rates for adults in Saskatchewan, 1979 to 1989

\section{RESULTS}

Table 1 presents the average monthly asthma hospitalizations by age group. The birth to four-year-old group had the highest rates of admission for asthma, with rates of 0.87 per 1000 in May and a low of 0.40 per 1000 in August. The lowest rates of admission were seen in the 15- to 34-year-old and 35- to 49-year-old populations. The asthma hospitalization rate for the 50- to 64-year-old group was highest in March, with a rate of 0.28 per 1000 .

Figures 1 and 2 present the seasonal patterns observed. The horizontal line in the centre represents the trend line for the age group. The trend line represents the local mean or the expected value of the rate for that month if no seasonal variation were present. The vertical bar for each month indicates the average fluctuation in rate about the expected value over the 11 years studied. A bar above the trend line indicates that on average, over the 11 years, asthmatics in that particular age group had more than the expected admissions in in a particular month; whereas a bar below the trend line indicates on average a lower than expected rate of admission.

In children aged birth to four years, the monthly seasonal pattern in the asthma hospitalization rates show increased admissions in the spring months of April, May and June and in 


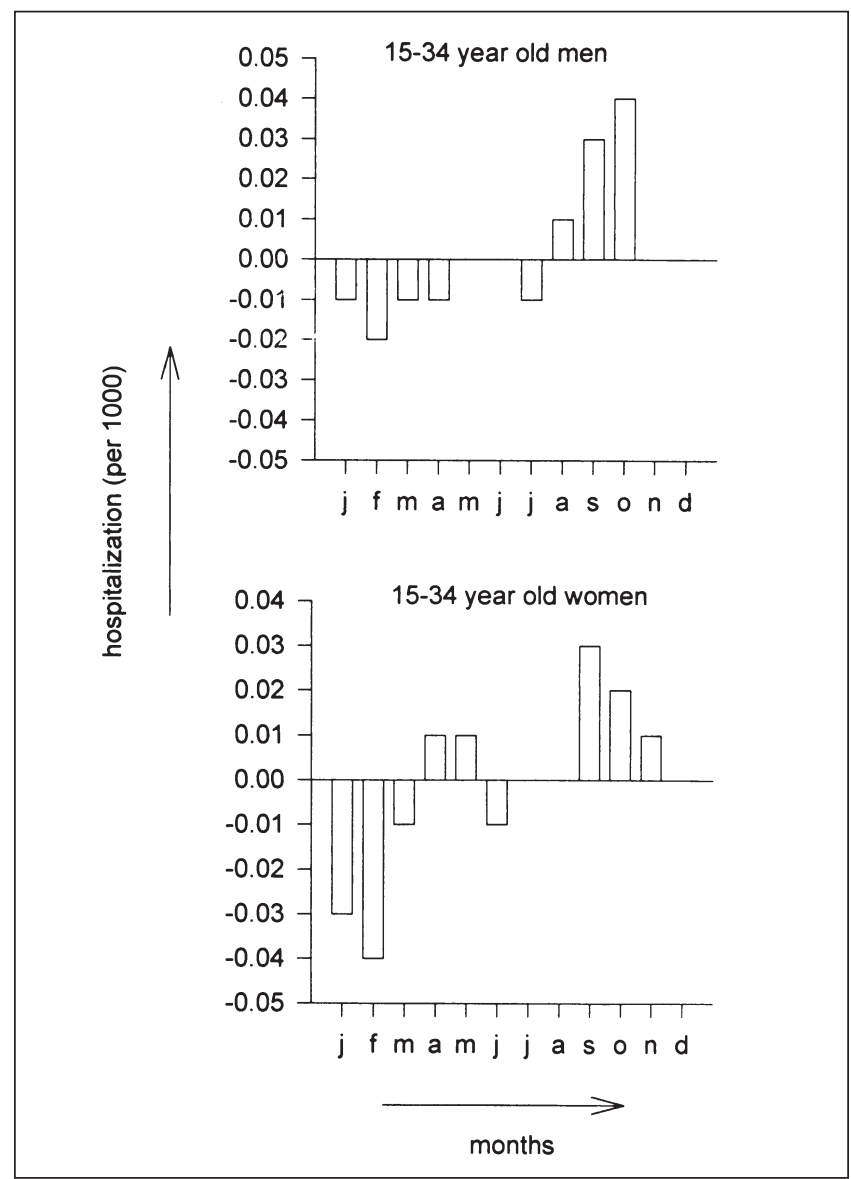

Figure 3) Seasonal patterns in asthma hospitalization rates for males and females aged 15 to 34 years in Saskatchewan, 1979 to 1989

the fall months of September, October and November; the seasonal pattern was statistically significant $(\mathrm{P}<0.001)$. A similar seasonal pattern was also observed in children aged five to 14 years $(\mathrm{P}<0.001)$ except that no increase was seen in November for this age group and that the peak in asthma hospitalization rates occurred in May for the youngest group of children compared with September for children in the five- to 14-year-old group (Figure 1).

Among young adults aged 15 to 34 years, asthma hospitalization rates increased in the summer months (July to September) and admissions decreased in January and February $(\mathrm{P}=0.0001)$ (Figure 2). There was no increase in spring for this group. No seasonal changes were observed in asthma hospitalization rates in spring and the early summer months.

The middle-aged group, 35- to 49-year-olds, marks a change in pattern, with asthma admissions increasing in winter months (Figure 2). Above average asthma admission rates are seen from January to April, and in October and December $(\mathrm{P}=0.002)$. In the older age group (50- to 64-year-olds), winter-spring increases become more pronounced. Seasonal changes in asthma hospitalization rates included increases in the winter months of December and January, and from March to May and decreases in the summer and fall months from July to November $(\mathrm{P}<0.001)$ (Figure 2).

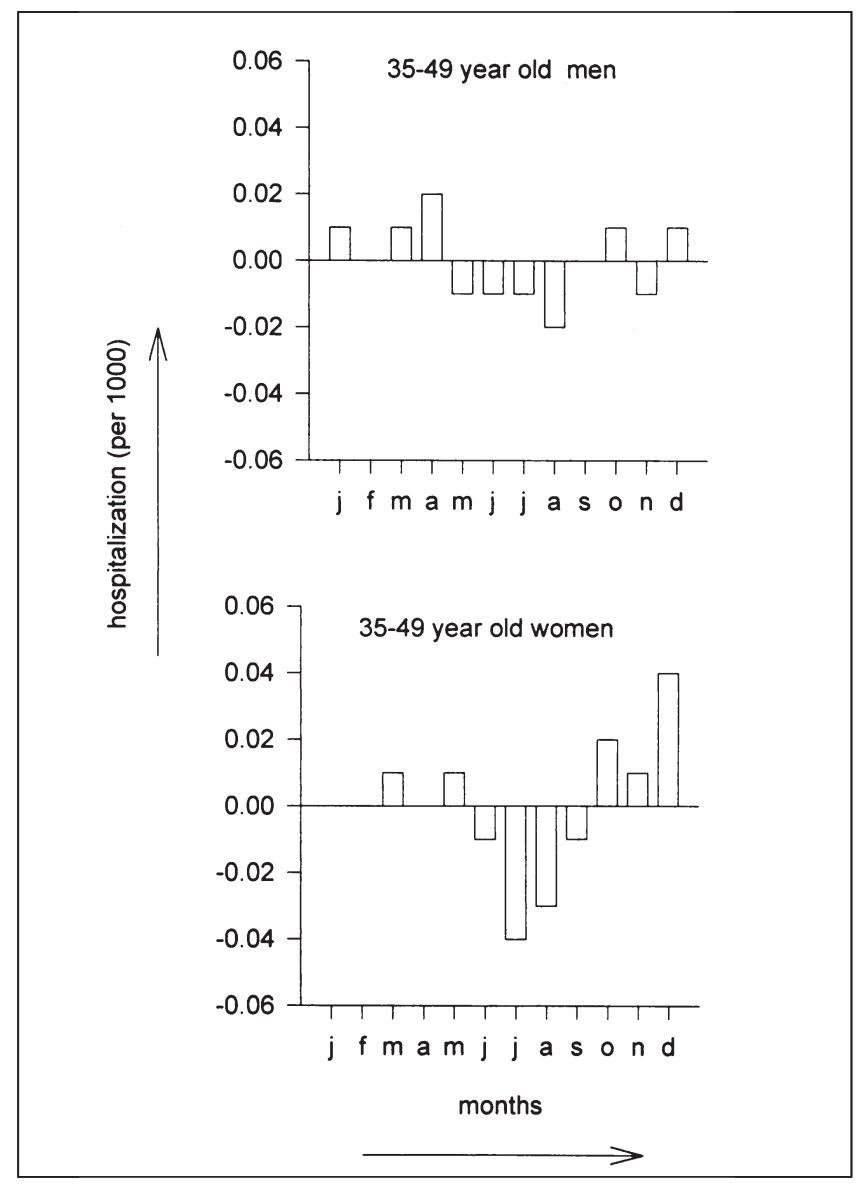

Figure 4) Seasonal patterns in asthma hospitalization rates for males and females aged 35 to 49 years in Saskatchewan, 1979 to 1989

A comparison of sex-specific patterns in the age groups studied revealed essentially the same patterns for children of both sexes. In young and older adults, interesting differences were observed in asthma hospitalization rates between male and female populations. However, none of the differences was statistically significant. In the 15- to 34-year-old age group, males had increased admissions only in the fall months; however, the women in this group experienced above average admissions in both spring and fall months (Figure 3). Among adults aged 35 to 49 years, seasonal pattern in asthma hospitalization rates was statistically significant in women $(\mathrm{P}=0.003)$ but not in men $(\mathrm{P}=0.16)$ (Figure 4). Women had greater decreases in asthma hospitalization rates in summer months than men. However, differences in the seasonal pattern between men and women were not statistically significant.

In the oldest group studied, men and women had statistically significant seasonal patterns that are quite similar. Both men and women had above average asthma admission rates in the spring months from March to May and in the winter months of December and January (Figure 5). The difference in the seasonal pattern between the men and women was that men had an increased admission rate in February, whereas women had a decrease. 


\section{DISCUSSION}

We analyzed monthly asthma hospitalizations in Saskatchewan 1979 to 1989 , inclusive. Diagnoses of asthma in these cases were assumed to be accurate. Misclassification of asthma with other respiratory conditions among young children and older adults has been reported $(5,22)$. Two Canadian studies have examined the validity of asthma diagnosis in hospitalization data. In a study conducted in Montreal, the authors (23) found $94.9 \%$ agreement between asthma hospitalization data and visits to the physician for asthma obtained in the universal health insurance database. In a second validation study conducted in Prince Edward Island, 69\% of asthma hospitalizations satisfied the criteria of asthma diagnosis stipulated in the Ninth International Classification of Diseases Code 493 (ICD-9 493) (24).

Trends in asthma hospitalization over the past 11 years in Saskatchewan have been studied (18). Hospitalization rates for asthma increased significantly among the birth to fouryear-old age group between 1979 and 1989 but not in any other age group (18). In our examination of the seasonal patterns in hospitalization data for asthma, we observed seasonal patterns specific to different age groups. The patterns seen in the children were increases in hospitalization rates for asthma in spring and fall, and decreases in winter and summer. School children had relatively higher hospitalizations in fall, whereas preschoolers had relatively higher hospitalizations in spring. Increases in asthma hospitalizations in spring may have been related to increases in tree and grass pollens (25). The onset of cold temperature and increases in viral infections in fall may account for the fall increase in asthma morbidity $(26,27)$. Increased exposure to respiratory viral infections in school may explain why school children have higher rates of hospitalization in the fall than in spring.

Young adults (15- to 34-year-olds) exhibit a seasonal pattern in asthma hospitalizations that is different from that of the children. This group had increased asthma admission rates only in the fall. However, when sex-specific patterns are examined, women had increased asthma admissions in spring and fall months, whereas men had increases only in the fall months. Women in this young age group may have school children, and thus they may be more exposed than men to infections brought home by children.

The 35- to 49-year-old group show a change in the seasonal pattern. Increased asthma admissions were observed in the winter and spring months. The decreased admissions seen in the winter months in the younger age groups changed into increases, a finding that is similar to results reported for other North American populations (11).

Sex-specific patterns show interesting differences between men and women. Although differences in seasonal patterns in asthma hospitalization rates between men and women were not statistically significant, women had a significant seasonal pattern in asthma hospital admission rates. Decreases in asthma hospitalization rates in the summer months were much greater for women than men. This may be partly related to differences in occupations of the two groups. In summer, grain farming is one of the main occupation of

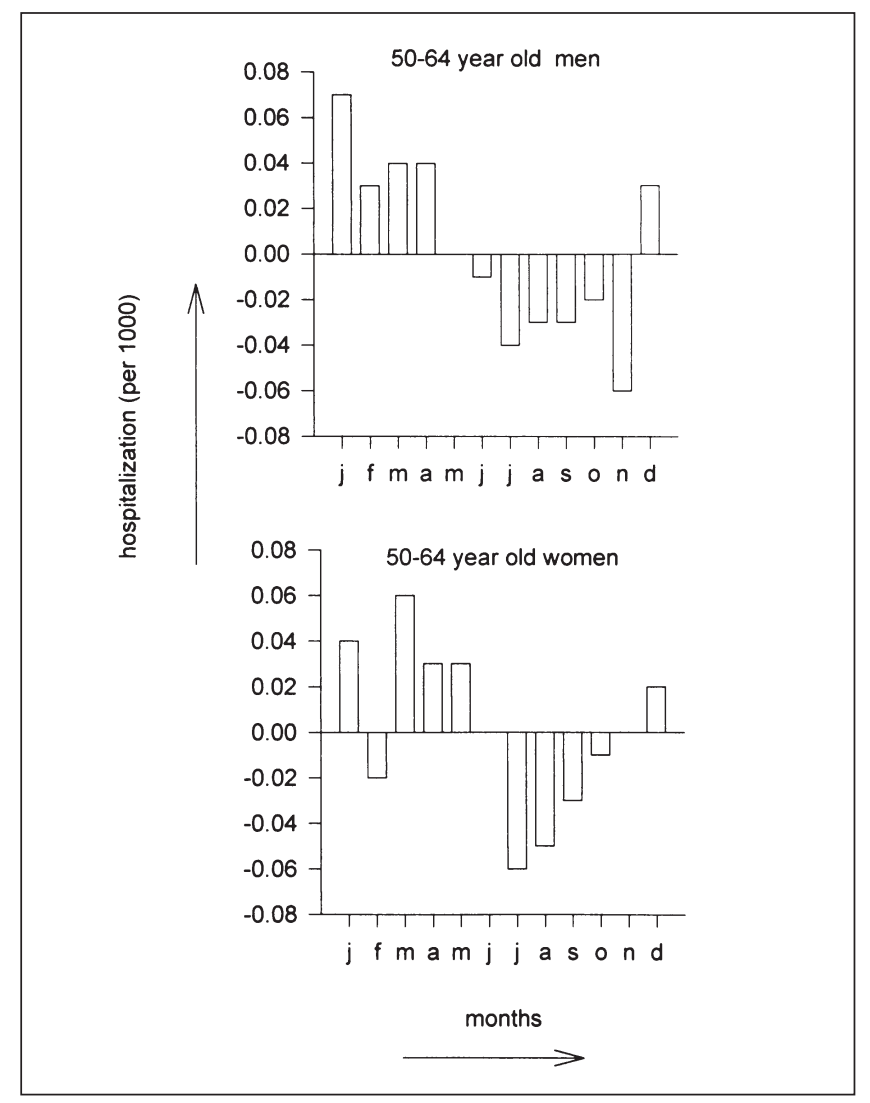

Figure 5) Seasonal patterns in asthma hospitalization rates for males and females aged 50 to 64 years in Saskatchewan, 1979 to 1989

men in Saskatchewan. In a recent study, a significant association between grain farming and asthma was observed in men but not in women (28).

The older group, 50- to 64-year-olds, also showed a seasonal pattern of increased asthma hospitalization rates in winter and spring months and decreased admissions in the summer and fall months. The reasons for these findings may be manifold. Higher winter values may relate to the increased prevalence of colds and other viral infections during this season. The pattern seen in this group is very similar to the general pattern of seasonality for respiratory disease (29).

A common feature of the seasonal patterns for all age groups was the decreased asthma hospitalization rates in the summer months. This may be related to the dry, hot weather of Saskatchewan's summer.

\section{CONCLUSIONS}

We have shown that asthma hospitalization rates vary with season in children and adults. This variation should not ignored in comparisons of asthma morbidity between different areas in large countries such as Canada, and between countries in the world. In several studies, asthma morbidity is compared between places $(12,30)$. If researchers ignore the seasons in which studies were conducted, they may draw incorrect conclusions when comparing asthma morbidity. More studies are required to examine possible reasons for the seasonal differences in asthma hospitalizations. 


\section{REFERENCES}

1. Mao Y, Semenciew R, Macwilliam L, Davies J, Wigle D. Increased rates of illness and death from asthma in Canada. Can Med Assoc J 1987; 137:620-4.

2. Burney P. Epidemiology of asthma. Allergy 1993;48:17-21.

3. Markowe HLJ, Bulpitt CJ, Shipley MJ, et al. Prognosis in adult asthma: a national study. BMJ 1987;295:949-52.

4. Van Neikerk CH, Weinberg Eg, Shore SC, et al. Prevalence of asthma; a comparative study of urban and rural Xhosa children. Clin Allergy 1979;9:314-9.

5. Khot A, Evans N, Lenney W. Seasonal trends in childhood asthma in southeast England. BMJ 1983;287:1257-8.

6. Britton J, Chinn S, Burney P. Seasonal variation in bronchial reactivity in a community population. J Allergy Clin Immunol 1988;82:134-9.

7. Khot A, Burn R, Evans N, et al. Seasonal variation and time trends in childhood asthma in England and Wales, 1975-81. BMJ 1984;289:235-7.

8. Ayers GJ. Trends in asthma and hay fever in general practice in the United Kingdom, 1976-83. Thorax 1986;41:111-6.

9. Storr J, Lenney W. School holidays and admissions with asthma. Arch Dis Child 1989;64:103-7.

10. Goldstein FI, Currie B. Seasonal patterns of asthma: A clue to etiology? Environ Res 1984;33:201-5.

11. Weiss KB. Seasonal trends in US asthma hospitalization and mortality. JAMA 1990;263:2323-8.

12. Ward DL. An international comparison of asthma morbidity and mortality in US soldiers: 1984 to 1988. Chest 1992;101:613-20.

13. Tseng TM, Lo CN, Ling WC, Mok MMC. Seasonal asthma in Hong Kong and its management implications. Ann Allergy 1989;63:247-50.

14. Strannegard LL, Strannegard O. Childhood bronchial asthma in a desert country. Allergy 1990;45:327-33.

15. Mao Y, Sememciw R, Morrison H, Wigle DT. Seasonality in epidemics of asthma mortality and hospital admission rates in Ontario, 1979-86. Can J Public Health 1990;81:226-8.

16. Bates DV, Baker-Anderson M, Sizto R. Asthma attack periodicity: A study of hospital emergency visits in Vancouver. Environ Res 1990;51:51-70.
17. Bates DV, Baker-Anderson M. Asthma mortality and morbidity in Canada. J Allergy Clin Immunol 1987;80:395-97.

18. Senthilselvan A. Trends and rural urban differences in asthma hospitalizations in Saskatchewan, 1970-1989. Can Respir J 1994;1:229-34

19. Senthilselvan A, Habbick BF. Increased asthma hospitalizations among Registered Indian children and adults in Saskatchewan, 1970-1989. J Clin Epidemiol 1995;48:1277-83.

20. Saskatchewan Covered Populations, 1979-1989. Health insurance registration information systems branch. Regina: Saskatchewan Health Department, 1989.

21. MacLeod AI, MacNeil IB, Bhattacharyta D. Seasonal effects in Canadian murders. Can J Stats 1985;4:262-75.

22. McWhorter PW, Polis MA, Kaslow RA. Occupancy, predictors and consequences of adult asthma in SHANES-1 and follow-up survey. Am Rev Respir Dis 1989;139:721-4.

23. Delfino RJ, Becklake MR, Hanley JA. Reliability of hospital data for population-based studies of air pollution. Arch Environ Health 1993;48:140-6.

24. Sweet L, Fan JSK, O’Neil J. A validation study of asthma, Prince Edward Island, 1984-1988: II. Hospitalizations. Chronic Dis Can 1992;13:19-23.

25. Platt-Mills TE, Hatden MI, Chapman MD, et al. Seasonal variation in dust mite and grass pollen allergens in dust from the houses of patients with asthma. J Allergy Clin Immunol 1987;79:781-91.

26. Holland WW, Spicer CC, Wilson JMG. Influence of the weather on respiratory and heart disease. Lancet 1961;ii:338-41.

27. Carlsen KH, Ostravik I, Leagard J, et al. Respiratory virus infections and aeroallergens in acute bronchial asthma. Arch Dis Child 1984;59:310-5

28. Senthilselvan A, Chen Y, Dosman JA. Predictors of asthma and wheezing: grain farming, sex and smoking. Am Rev Respir Dis 1993; 148:667-70.

29. Scragg R. Seasonal variation of mortality in Queensland. Commun Health Studies 1982;6:120-9.

30. Woolcock AJ. Worldwide trends in asthma morbidity and mortality. Explanation of trends. Bull Int Tuberc Lung Dis 1991;66:85-9. 


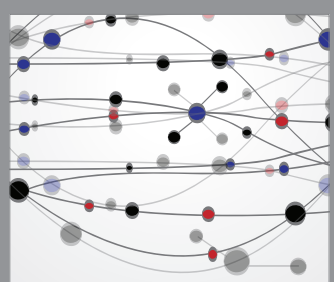

The Scientific World Journal
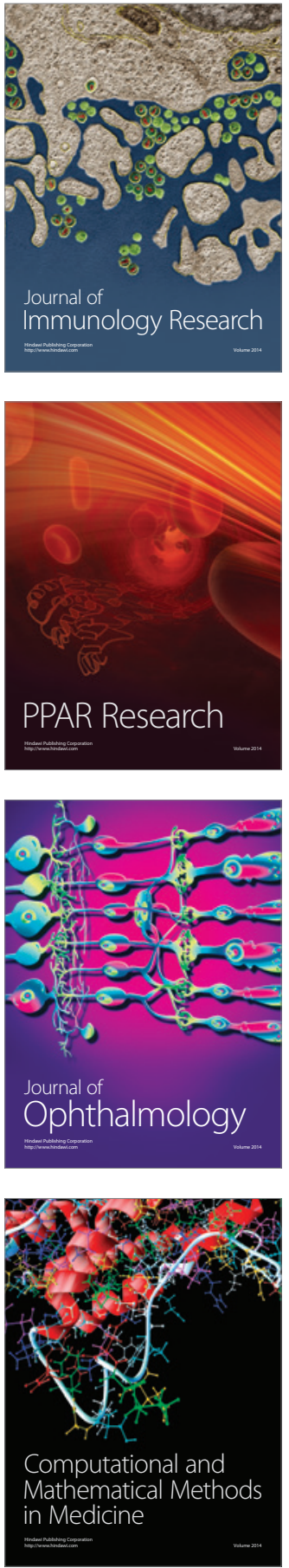

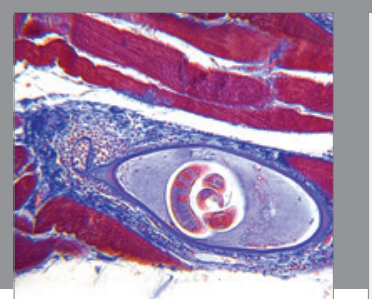

Gastroenterology Research and Practice

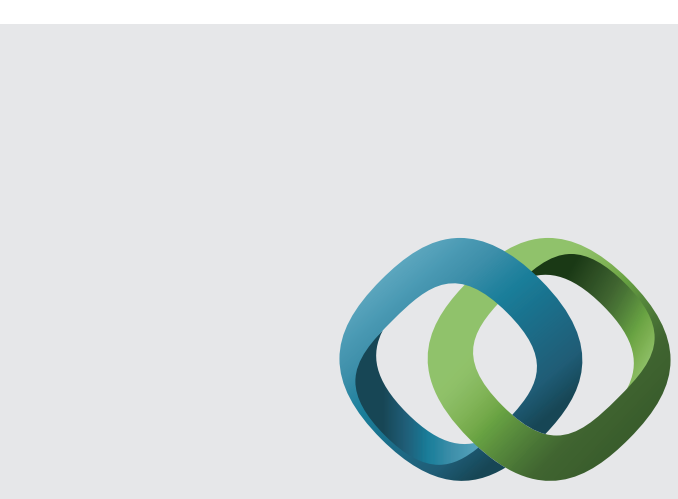

\section{Hindawi}

Submit your manuscripts at

http://www.hindawi.com
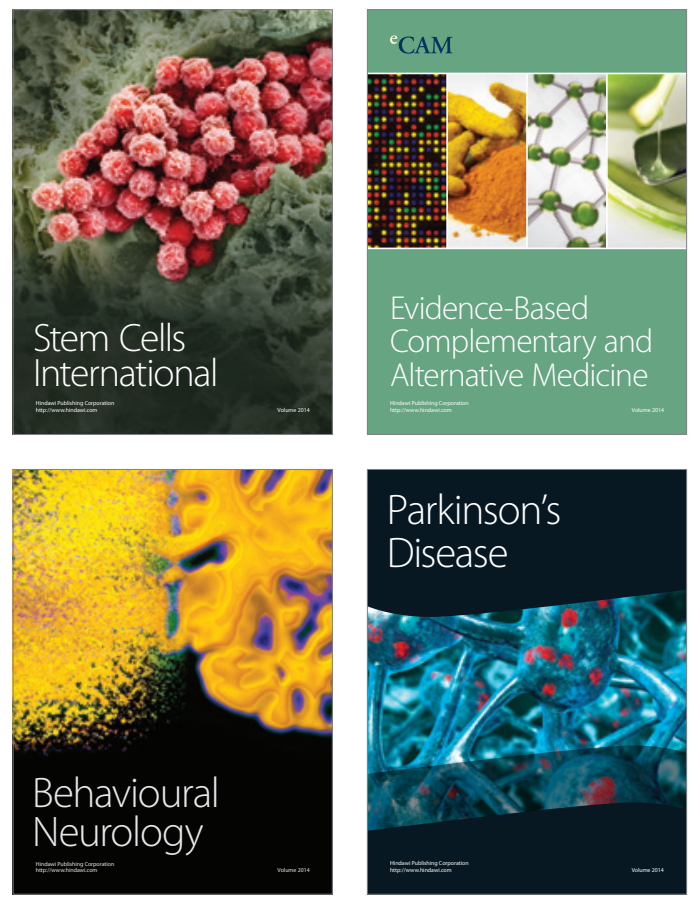
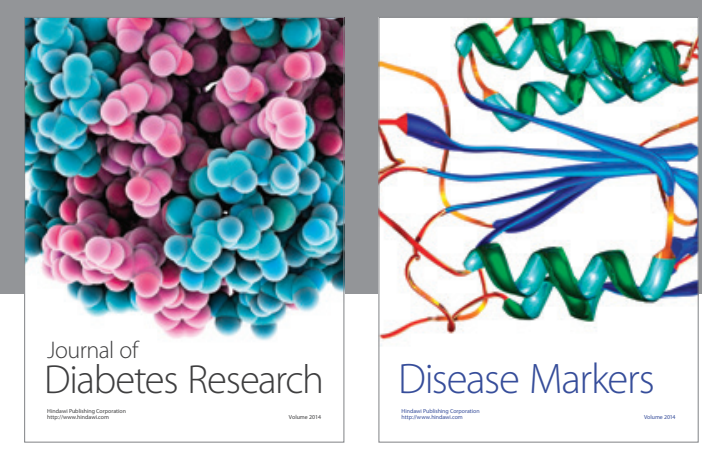

Disease Markers
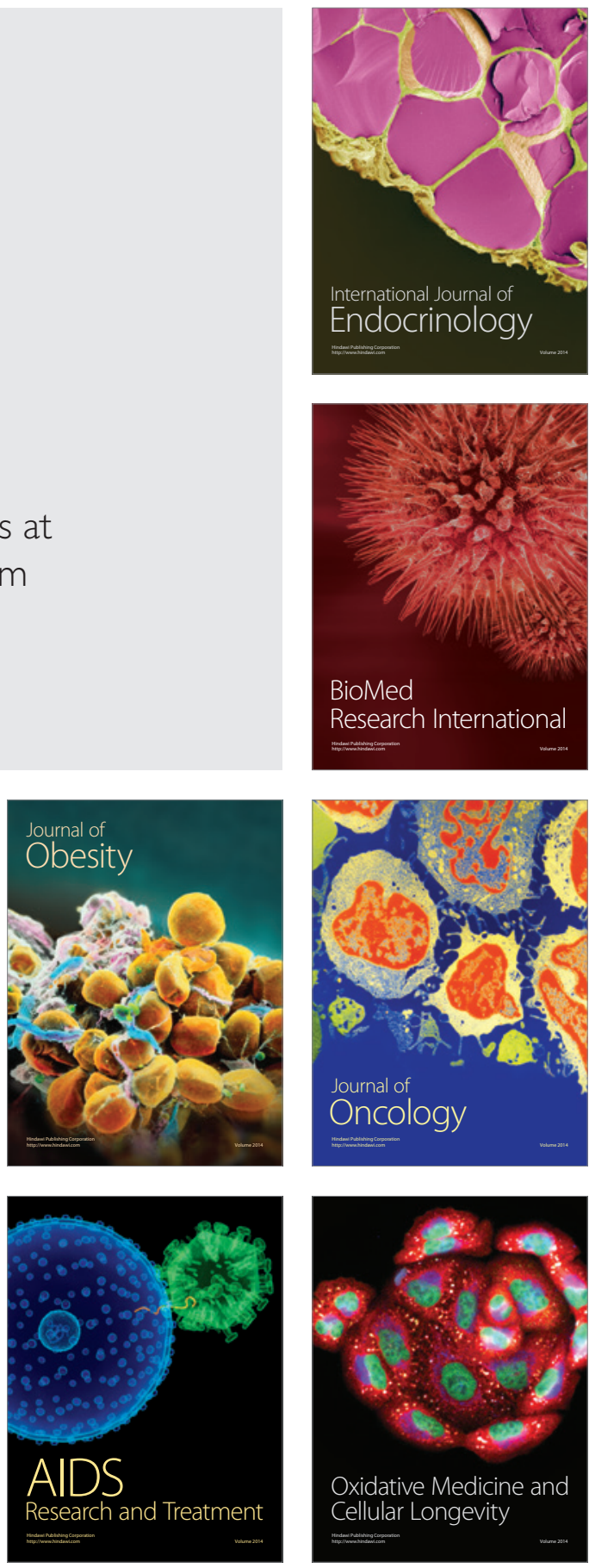